\title{
Research Paper: Strategic Planning of Rural Tourism Development Using SOAR Model: A Case Study of Kandovan Village
}

\author{
Mohammadamin Khorasani ${ }^{*}$, Leila Hatami², Davood Kiakojoori ${ }^{3}$ \\ 1. Assistant Professor, Department of Human Geography, Faculty of Geography, University of Tehran, Tehran, Iran. \\ 2. MSc., Department of Management, Faculty of Management, Maziar University, Noor, Iran. \\ 3. Assistant Professor, Department of Management, Chaloos Branch, Islamic Azad University, Chaloos, Iran.
}

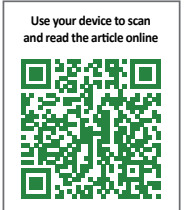

Citation: Khorasani M., Hatami, L., \& Kiakojoori, D. Strategic Planning of Rural Tourism Development Using SOAR Model: A Case Study of Kandovan Village. Journal of Sustainable Rural Development, 1(2), 171-188. https://doi.org/10.29252/jsrd.01.02.171

https://doi.org/10.29252/jsrd.01.02.171

Article info:

Received: 03 Feb. 2017

Accepted: 20 Jun. 2017

Keywords:

Strategic planning, Rural tourism development, Heritage tourism, SOAR model,

Kandovan

\section{ABSTRACT}

Purpose: This research aims to perform strategic planning of tourism development in Kandovan village using SOAR model. This model is a combination of SWOT strategy and Appreciative Inquiry (AI) introduced by Jacqueline M. Stavros. AI, instead of focusing on problems such as weaknesses and threats, identifies strengths and creates promising opportunities.

Methods: In this study, library and semi-structured interview methods have been used. The present study is a qualitative research in terms of nature and method of data collection. The statistical population of this research includes villagers of Kandovan, government officials, and NGO's related to Kandovan village, in Osku County, near Tabriz metropolis, and tourists visiting the Kandovan village in the summer of 2016. In this research, the qualitative content analysis technique was used in the framework of inductive approach in accordance with the SOAR strategic planning model. Then, four SOAR strategic model indicators, i.e. strengths, opportunities, aspirations and results were extracted.

Results: The results of the research indicate that for implementation of UNESCO's architectural standards to world village registration, it is necessary to construct a new Kandovan next to the old village. In addition, holding festivals, exhibitions and weekly markets for the development of regional tourism is recommended. Establishment of tourism amenities such as construction of parking lots, recreational complex, designing websites and construction of a hotel are some other recommendations. Holding training courses related to tourism in the village, is a major step towards development of tourism considering the potential among the youth of the village.

Conclusion: Villagers require to learn a series of educational courses. The youth of the village continue to do their business in the village and commute between the village and the city they live during the tourist season. Considering the young generation's loyalty to their hometown and their desire to work in their village, many of them are ready to participate in the development of tourism of village and, as a result, holding educational courses from the Cultural Heritage and Tourism Organization of the region such as foreign language courses, tourism guides, hospitality culture, marketing and advertising are welcomed by young people.

* Corresponding Author: 


\section{Introduction}

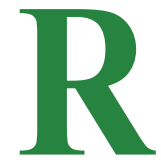

ural tourism, as a recreational and social activity, appeared in Europe in the second half of the $18^{\text {th }}$ century, and since 1945 the rapid growth of demand for it has emerged, with the development of transportation (Firouzabadi \& Ghasemi, 2009). Rural tourism is a part of the tourism industry, which can play a major role in empowering local people and diversifying the growth of the economy as well as creating new employment opportunities in close relation with other economic sectors (Sharifzadeh \& Moradinejad, 2002). In recent years, rural tourism has been considered one of the most important drivers helping local communities to develop economic activities. In this regard, the special significance of tourism industry is due to the growing and flourishing economic interactions between different sectors of the economy and between rural and urban communities and different ethnic groups and nations (Rogerson, 2004: 15).

Rural tourism development is often seen as a tool for rural economic development and rural regeneration (Wilson, Fesenmaier, Fesenmaier, \& Van Es, 2001; Lane, 2009; Mair, 2006; Sharpley, 2007; Williams \& MacLeod, 2005; Sharpley \& Craven, 2001; Sharply \& Vass, 2006; Scott, Christie, \& Midmore, 2004; George \& Reid, 2005). Rural tourism, as an important form of using rural environment, allows us to understand the concept of rural simplicity in the context of touristic representations (Bell, 2006). Many believe that tourism development have a profound effect on the structure and capital of rural areas (Girard \& Garner, 1993). Experience has shown that, wherever tourism is developed accidentally and without any specific planning and strategy, many environmental and social problems have emerged, and in the long term tourism problems overshadow its benefits (Roknoddin Eftekhari \& Mahdavi, 2006). As a result, more comprehensive planning is needed to develop coordinated approaches for development consistent with predictable and unpredictable requirements of the future (Bahrami, Naderi Khorshidi, \& Kasirinejad, 2010:12).

Strategic planning of tourism development in the cliff village of Kandovan was carried out considering its high potential in the field of tourism. The beautiful and historic village of Kandovan is located $22 \mathrm{~km}$ from the city of Osku, which is $62 \mathrm{~km}$ from the Tabriz metropolis in the high mountains, on the northern slopes of Arshad Daghi and the western part of Sahand volcanic masses, covering widespread nomadic pastures. The stone pyramidal house of this village, which has a rocky architecture, is unique. The village has many tourism attractions, mainly due to the shape of its houses, which are hollowed out in the mountains. In fact, what has given archaeological and historic identity to Kandovan is the life of 117 families and dwelling houses within the conical and pyramidal masses of rocks. One can say that the name of Kandovan is derived from its hive houses (Kando in Persian) that are located in the heart of these cone rocks (Akbari \& Bemanian, 2008).

In total, 3 rocky villages have been identified in the world, the Cappadocia village in Turkey and Dakota in the United States and Kandovan in Iran. Out of them, only Kandovan village in Iran has a residential population. Therefore, the purpose of this research is to develop a strategic plan using the SOAR model for Kandovan rocky village. The architecture of the Kandovan village and the people's lives in the context of its ancient texture is an exception in the world. Kandovan is a village built on the rock, and the only building materials of this village are rocks. The houses are pyramidal and have holes in the rocks for livestock, so it has the potential to attract tourists from inside and outside of Iran. The strategic planning for sustainable development is to increase domestic and foreign visiting tourists, revitalize the traditional village texture and preserve the ecotourism attractions of the region. The aim is to promote and boost economic development of the village and prevent the migration of villagers to neighboring cities and increase the living standards of local people. So, main question of this research is: What are the best participatory strategies for rural tourism development in historic and legacy village of Kandovan?

\section{Literature Review}

\section{Heritage tourism in rural areas}

One of the strategies considered in recent years, especially in developed countries and brought positive results, is the development of tourism in rural areas and the use of many natural and cultural attractions as a source of income for the people of the villages, while helping to protect the unique natural and cultural attractions of the village (Ashley, Roe, \& Goodwin, 2000). Rural tourism is a form of tourism development that provides the basis of cultural, historical, economic, social and cultural development and preserves cultural heritage through attracting tourists in rural areas (Figueiredo Raschi, 2013). Cultural diversity and natural landscapes of villages provide an important background for the development of tourism (Garrod, Wornell, \& Youell, 2006). 
Studies of tourism incentives in villages show that proximity to nature is the most important factor in the attractiveness of villages (Fleischer \& Pizam, 1997). However, rural culture and lifestyle is an escape from everyday life and the proper quality of time spending with family and friends are also other most important motivations of rural tourists. The psychological aspect of rural tourism also manifests itself in the form of psychological promotion and valuable experiences (Molera \& Albaladejo, 2007; Park \& Yoon, 2009; Sharpley, 2007). Tourism has the capacity to revive the heritage and culture of rural communities and represent the people, communities, and local lifestyles (Garrod et al., 2006).

Heritage attractions bring people into contact with the tangible remains of the past, the relationship that sometimes we want to experience and celebrate in our ultimate endeavor. In fact, heritage attractions are multipurpose. They can provide a range of enjoyable leisure experiences, be the focus of social identity, a source of educational goals, and tools for economic development.

The perceptions and mental attitudes of individuals are the main elements of the heritage tourism experience and therefore are very important and need great consideration. Since the heritage tourism is formed in the experimental environment of the heritage, people see places of the heritage to increase their sentiments, satisfy their curiosity and nostalgia, grow spiritually, relax, and move away from their usual place of life. Tourists do not come to heritage sites due to physical objects, but in search for various cultural experiences, ideals and identity pride and have personal emotional interaction (Timothy, 1997).

In studying Mauri community in New Zealand, McIntosh et al. (2002) have considered four approaches to tourism development. They introduced the term "attraction-based identity," where the identity of a local community should be formed or adapted to create cultural tourism experience in a targeted way. Attraction-based identity originated from the Prohansky's place identity, an attempt by individuals with a specific culture to represent their identity and values as a recreational tourism experience (McIntosh, Hinch, \& Ingram, 2002:42). Six factors are crucial for sustainable marketing to happen and succeed. For effective results, these factors should be internalize into the marketing plan. These are local community involvement and benefits, partnership and collaboration, authenticity and conservation, visitor mindfulness, interpretation, and economic viability.
We need to implement 'inclusive strategies' not only within the context of heritage presentation and interpretation but also get involve local communities in the tourism planning and development process. Inskeep (1991) and Pearce (1995) described the significance of involving the local community in decision-making processes pertaining to heritage tourism development.

Partnerships from a sustainable tourism perspective imply the need to collaborate with various stakeholders to aim for sustained use of resources. Partners within the heritage tourism environment have been broadly classified into the following categories: heritage institutions (heritage sites, attractions, events, and shops), the public sector (chamber of commerce, city or government who decides on tax deductions), the ancillary sector (such as gasoline stations, restaurants, lodging, gift shops, etc.), tourism organizations (such as the convention and visitor bureaus, state tourism offices, national and regional tourism organizations), local community, and the academic community (the educational institutions).

Conservation of heritage is important. The primary basis of conservation includes protection of heritage resources. It emphasizes the purposeful use of resources in a manner that it is appreciated and used for recreational purposes while at the same time strive to sustain the core value of heritage for future generations (Pearce, 1997). Appropriate information and their behavior needs to be managed to minimize misuse and disrespect of heritage resources. Literature has extensively referred to Tilden's guiding principles of interpretation to achieve effective interpretation. These suggest inclusion of personality and life experiences of the visitors, inspiring qualities, need to be provocative, holistic, and follow a fundamentally different approach when addressing different groups.

The underlying premise, within the context of sustainability, is that mindful visitors are more sensitive and attentive to the environment around them. According to Moscardo (2001), the main features of visitor mindfulness include receptivity to learning, awareness of the setting, and development of new routines. Thus the conditions that support visitor mindfulness are new and different settings, control and choice, different and changing situations, and personal significance. An endless struggle has emerged between viability of the market and authentic representations of local heritage. In addition, this has resulted occasionally in a "commercial (and political) screening and packaging of reality. What tourists guided through are often not profitable 'pseudoevents' reflective neither of past or present realities" (Urry, 1990:98). 
Study area

The role of tourism as a new source of employment, earning, receiving more taxes, attracting foreign exchange, and strengthening social infrastructure that encourages the growth and development of other industries, has been confirmed in numerous studies (Lankford \& Howard, 1994:122). Thus, tourism development is widely accepted, especially in developing countries, and is on the agenda of governments (Ko \& Stewart, 2002:523). Today, tourism in rural and remote areas has become especially important, as it contributes to the economic prosperity of villages. Most rural areas of Iran have high potential for tourism. Kandovan village is considered not only as a village with geographical, environmental, natural, historical, and cultural features.

Because of its favorable mountain climate, tasty mineral water, fertile plains and peaceful environment as well as rural houses architecture, this village attracts many tourists each year. According to tourism organization report of East Azerbaijan Province, about 600000 people visited this village in 2006. Kandovan in spite of its appropriate opportunities has many problems for the development of tourism, such as unsuitable facilities of tourism infrastructure (camping, parking, and water closets), pollution and open sewage in the passages, destruction of orchards and farms and irregular and inconsistent construction with original architecture of the village. These have undesirable effects on unique and special context of Kandovan. As a result, in some parts of the village, it is not possible to see old conical houses and new buildings with undesirable quality and irregular architecture have replaced them (Ghasemzadeh, 2013). Figures 1 and 2, show satellite image and a landscape from kandovan's houses, Respectively.
According to renowned archeologists, David Roll and Peter Martini, Kandovan dates back to ancient times. They even claim it as the Garden of Eden, where Adam and Eve lived (Moghimi Oskoei \& Mosazade, 2007:221). Villagers have selected a practical, optimal, and easy way to build and utilize space. In Kandovan, it is tried to use more by less space (Daneshpour, \& Pajouh, 2013). Over 850 years old (Eslami, \& Sabri, 2008:51), the village of Kandovan displays houses and barns carved entirely inside pyramidal cliffs. The architectural methods used are the most practical ways of utilizing the dome-shaped cliffs to make inhabitable places. The village situated in Sahand mountains, whose lush pastures hold great appeal for many nomadic tribes in search of food for their livestock. Numerous papers and conferences on Kandovan village have focused on the key factors distinguishing it from the other similar structures in the world, such as the rock houses in Cappadocia, Turkey and the cliff dwellings in Mesa Verde, Colorado, USA, all of which are long deserted.

\section{Methodology}

SWOT 6 model is one of the strategic models used in developing rural tourism. However, after so many years of using and evaluating this model, it has been concluded that the emphasis on weaknesses and threats leads to overlooking strengths and opportunities, and unconsciously, the process of developing a strategy moves toward negative and preventing points. As a result, scholars combined the SWOT technique and Appreciative Inquiry (AI) to create the strategic model of SOAR (Rezaei \& Khavarian Garmsir, 2014). So far, there has been a lot of research about strategic planning of tourism development in Iran, most of which are based on the traditional SWOT model and statistical tests. This research is the opening in using SOAR strategic model in tourism

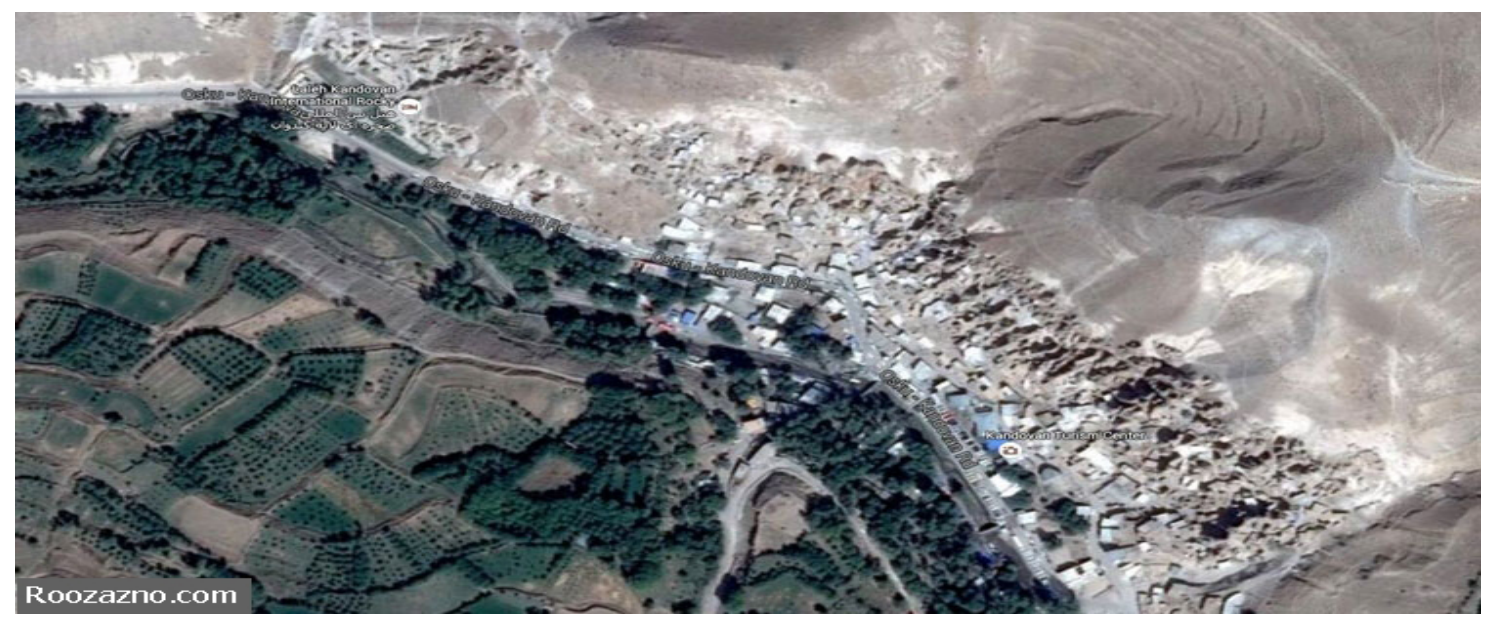

Figure 1. Satellite Image of Kandovan 


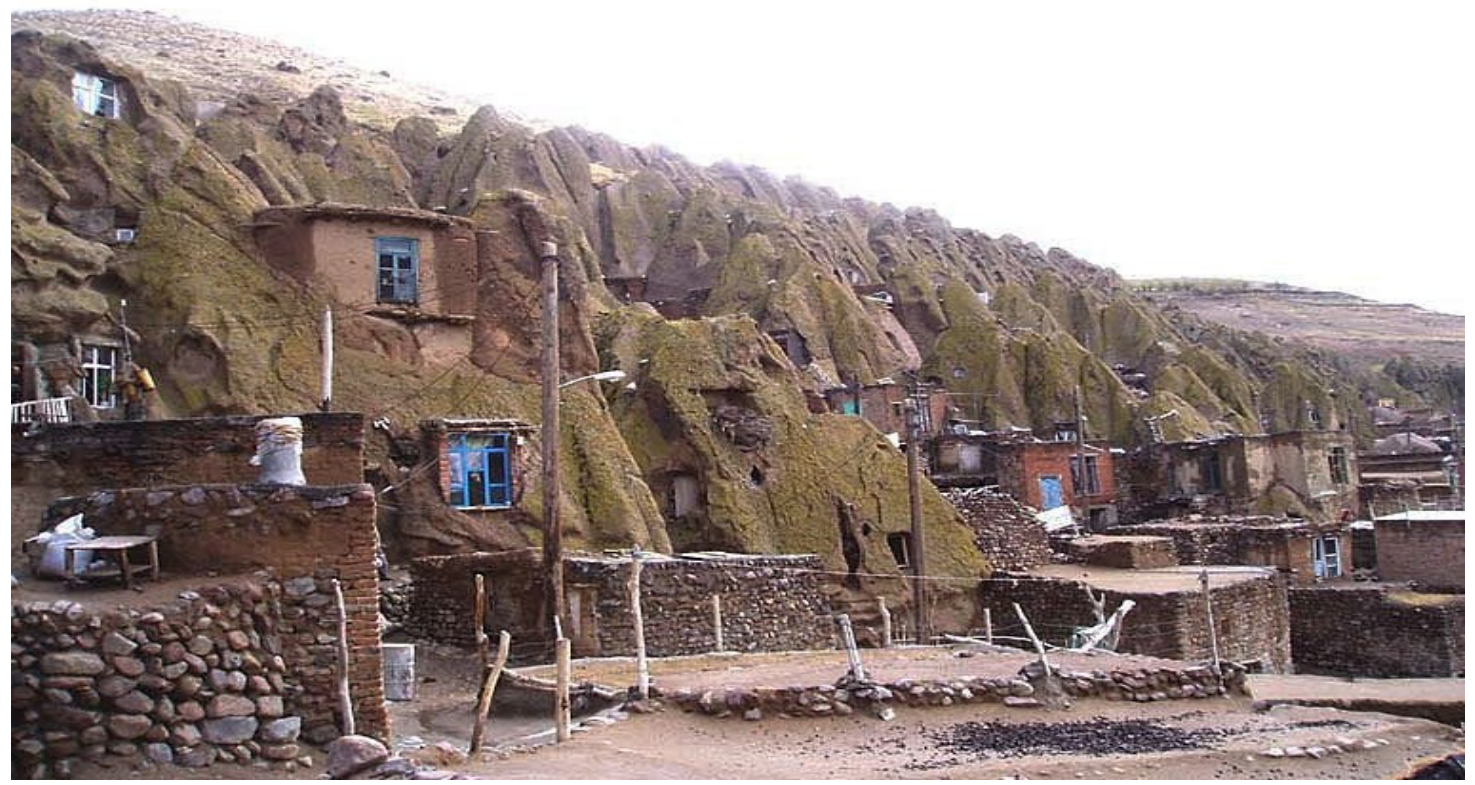

Figure 2. Kandovan village

studies. This model is a combination of the SWOT strategy and AI introduced by Jacqueline M. Stowers. This model has so far been used in business (Stavros \& Saint, 2009), management (Silbert, \& Silbert, 2007), success (Kumar, 2005), educational matters, and recently in tourism issues. For speeding up strategic plans, SOAR strategy focuses directly on those elements that create vital energy and a good incentive for the future. This vital energy is within the people. It is created through the relationships and dialogue between and among the people who have a share in the community. It should be noted that we are facing with a strategy based on the strengths, through which all people in the community share a contribution to create a shared vision, this process generates energy and commitment to achieve the desired outcomes (Stavros \& Sprangel, 2008). Appreciative Inquiry (AI) in a strategic planning identifies current strengths and creates promising opportunities instead of focusing on problems, weaknesses, and threats. In the traditional process of strategic planning, SWOT strategy includes strengths, opportunities, weaknesses, and threats (Karppi, Kokkonen, \& Lähteenmäki Smith, 2001), and if we want to divide it into two parts in terms of intellectual order, we must allocate half of our time to the positive points and the other half to the negative ones. The person inherently tends to focus on negative points. In AI, positive points and the opportunities are developed so that we can cover the weaknesses and threats (Stavros, \& Hinrichs, 2011:5).

The benefits of AI in strategic planning are as follows: 1. Focusing on positive points so that negative points are covered; 2. Creating abilities beyond the current realm; 3. Connecting contributors; 4. Gain input from all levels; 5 ; Converting planning into a process that brings together values, goals, and missions, and transforming them to strategic goals, positive and targeted review of goals; and 6. Creating perspectives and values for participation in the future (Stavros, \& Hinrichs, 2011).

In Figure 3, the framework for AI is demonstrated. In order to analyze the data from qualitative content analysis and present the strategy of rural tourism development, we used SOAR strategy model. Today, there are different approaches for strategic planning. SOAR is a new approach that has made it possible to achieve better results compared to other models due to reliance on positive attitude and strengths, as well as opportunities and ideals. There are four key factors in SOAR: 1. strengths, 2. opportunities, 3. ideals, and 4. results (Khavarian Garmsiri, Stavers, \& Aliyan, 2013). There are four strategies for the SWOT matrix. This technique is based on strengths, weaknesses, opportunities, and threats. This model is used in most cases at high levels of management. Four key factors in the SOAR model are as follows: 1. determining our biggest assets and positive aspects; 2 . determining best opportunities we are facing with; 3 . setting our ideal and favorite future; and 4 . determining the best measurable results.

The tools for collecting data and information comprised referring to documents, observation and interview. In this research, library studies were used to review the relevant literature and identify their variables and components. In 


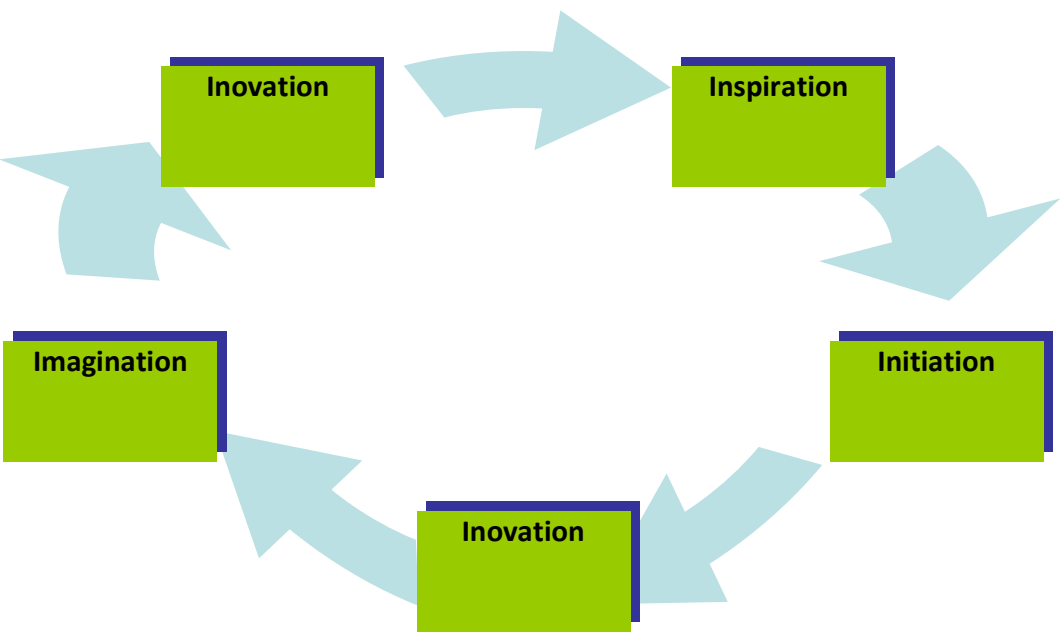

Figure 3. Theoretical framework of appreciative Inquiry (Stavros and Hinrichs, 2011)

the next stage, field research and a semi-structured interview technique were used. Considering the fact that this research had three different statistical societies, so for all three statistical societies, different questions were designed for semi-structured interviews. First the core of the planning team were identified and then the beneficiaries in the first stage. In the process of this research, the planning team were formed of writers. Beneficiaries and the people who had the role in this work were also identified including people from Kandovan (20 people); government officials related to Kandovan village, Osku City, Tabriz and East Azerbaijan Province (7 people); and tourists visiting the Kandovan in the summer of 2016 (20 people).

Theoretical sampling method was used to select the present samples among tourists. This means sampling is purposeful and focuses on modeling. Theoretical sampling is a method in which the researcher collects relevant data to refine and construct the categories needed to construct the model. In theoretical sampling based on the researcher's theoretical sensitivity, deep interviews with tourists go so far as to reach theoretical saturation. On this basis, the sample size for the residents of the village of Kandovan who reside in the village and provide tourism services is 20 , the sample size of the officials of the executive branch in tourism is 7 , including the head of the village of Kandovan, chairman of the council of Kandovan, governor of the Osku County, the head of the Cultural Heritage and Tourism of the Osku County, the tourism deputy of the East Azerbaijan Province and the two cultural heritage employees of the East Azerbaijan Province (experts in the field of tourism) and the sample size of tourists visiting the Kandovan village in the summer of 2016, were 20, who were identified through snowball method. The researcher, during a few weeks' stay in this village, did semi-structured interviews with the statistical community and recorded each interview word by word to extract the data necessary for qualitative analysis. Initially, an interview was conducted with the tourists of the village, and at the same time, familiarity and confidence was made with the villagers. An interview with the medical staff was also carried out, while identifying the village head and members of the village council as well as those involved in the rural tourism.

Afterwards, the follow up and exploratory questions were asked in order to clarify the concept and to deepen the interview trend. The content of interviews were analyzed after each interview, using the qualitative content analysis technique (in the framework of the inductive approach) in line with SOAR strategic planning model. The following steps were followed in order to analyze the data:

\section{First stage}

\section{Step 1: Transcribing the conversations and identi-} fication of the meanings

In this step, conducted conversations from each individual were transcribed and important and necessary items were extracted and categorized in the research trend after each interview (including residents of Kandovan, officials, and tourists).

\section{Step 2: Summarizing and categorizing the data}

After the first step, all data were placed in a semantic category by frequent reviewing of texts and the confron- 


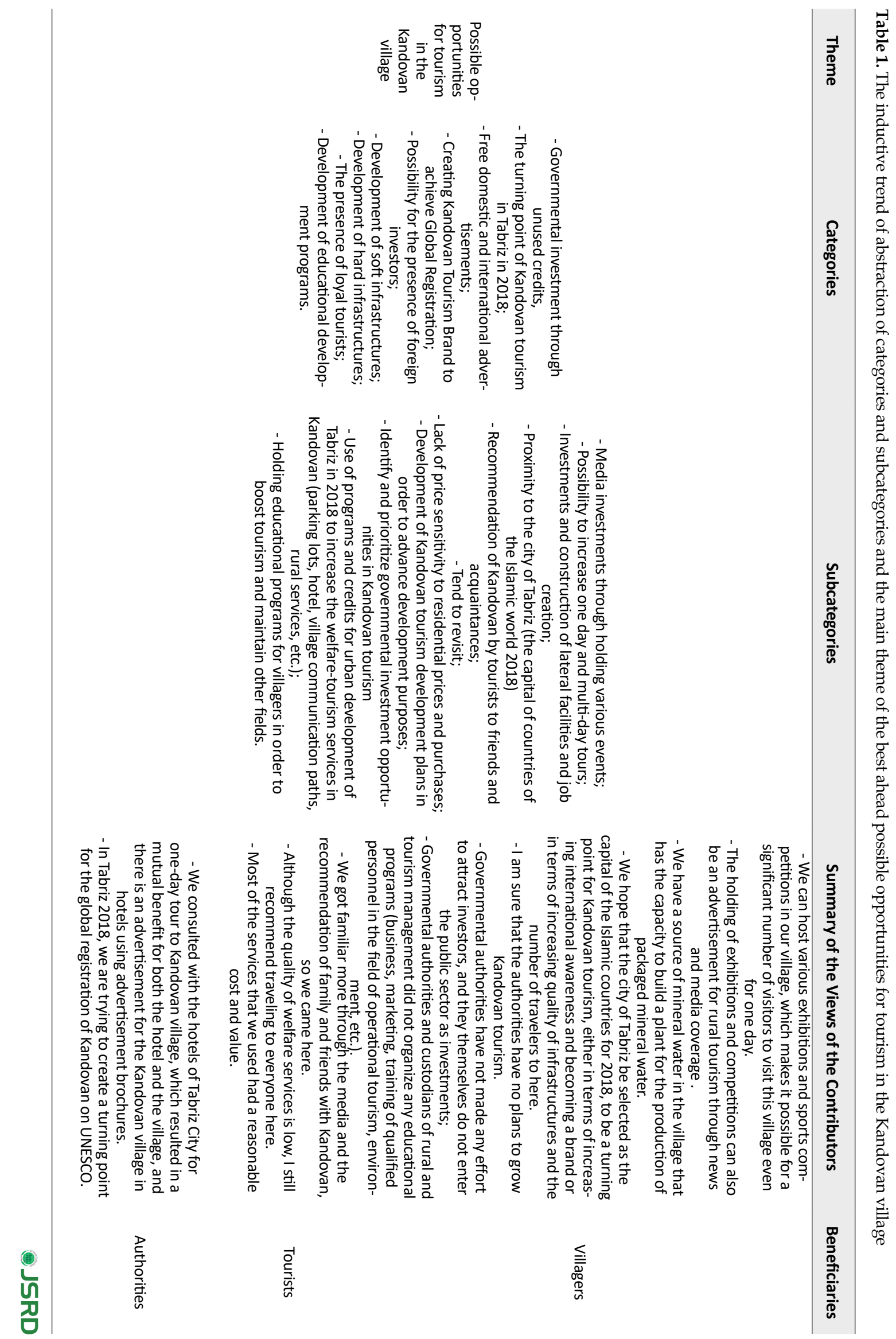


tation with various meanings that a common expression has been repeated several times or sometimes had been quite similar. Also extracted meanings that pursued the same purpose were placed in a semantic category based on differences and similarities.

Step 3: Reducing the subcategories with the purpose of extracting the categories

After the abstraction, the subcategories that have been taken from the meanings were categorized and coded according to the similarities and differences between the subcategories in more general categories.

Step 4: Extracting the main themes in regard to the SOAR model

In step 4, the categories were combined with orientation of the components of the SOAR model (opportunities, strengths, ambitions, aspirations, and results) by frequent comparing and revising the categories and based on their differences and similarities. This stage is called the selected encoding. Outputs of this process are shown in Table 1.

\section{Second stage}

Finally, strategic planning of tourism development in Kandovan was compiled and prepared based on the components of SOAR strategic model; opportunities, strengths, aspirations and obtained results after the preparation of the themes (strengths and opportunities). The first theme was defined for these strengths of tourism in the Kandovan village (the largest assets and positive aspects) based on SOAR's optimistic strategic model.

\section{Findings}

The core of the planning team and the beneficiaries were identified during this research in the first stage. In the process of this research, the planning team was formed of writers. Beneficiaries and the people who had the role in this work were identified as residents of Kandovan village (20 people); government officials related to Kandovan village, Osku County, Tabriz and East Azerbaijan Province (7 people); and tourists visiting Kandovan in the summer of 2016 (20 people). In the first stage, four steps of data analysis, which included transcribing interviews and identification of the meanings (step 1); summarizing and categorizing the data (step 2); reducing the subcategories with the purpose of extracting the categories (step 3) and extracting the main themes, which are the strengths and opportunities here, was done in line with the SOAR model (step 4). The study interviews were initially conducted with the people of Kandovan village and at the same time, interviews were conducted with tourists of the region. Finally, after gathering the views of the interviewees of the villagers and tourists, we interviewed the officials of the village of Kandovan, including the village official and village council and the prefect of the Osku County, the Head of the Cultural and Tourism Heritage Department of Osku, Deputy Director of Cultural and Tourism Heritage of East Azerbaijan Province and several officials related to the field of tourism. Summary of the views of the contributors is shown in Table 2.

\section{Turning strength and opportunity into aspirations}

The strategic planning of tourism development in Kandovan village based on the themes that were extracted in the first stage (strengths and opportunities) was continued according to the components of the SOAR strategic model in the second stage. In this stage, the internal strengths and external environment were used to create the opportunities and turn them into aspirations and then (Table 3) to determine the strategy by means of exploring and recognizing the values and perspectives. The collection of strengths and opportunities and its adaptation to the aspirations and finally, the compilation of results were examined in the next section, from the second stage (Table 4). In addition, a collection of strengths, opportunities, ideals, aspirations, and results were reviewed and its summary was reported in this section of the research process. These results are as strategic plans for tourism development of Kandovan based on the components of SOAR strategic model.

\section{Discussion}

Rural tourism relies on its capacity to provide an alternative way of development, investing in the specific assets that have capability of attracting special interest or niche tourism. A first expression of rural tourism development based on a range of special interest or alternative tourist activities is cultural heritage tourism (Sharpley, \& Craven, 2001). "It devotes to and presents cultural ideas of local people, it is small scale and frequently targets up-market segments". Furthermore, cultural tourism adds to cultural revitalization in host communities, as it generates pride in local traditions (Misiura, 2006; Piccard, 1996). Robinson and Smith (2006) argue that "In situations where there is a more level playing field between stakeholders, cultural tourism is arguably easier to establish." Cultural heritage tourism can be encouraged and is an effective framework for community involve- 
Table 2. The inductive trend of abstraction of categories and subcategories and the main theme of the strengths (the largest assets and positive aspects) tourism of Kandovan Village

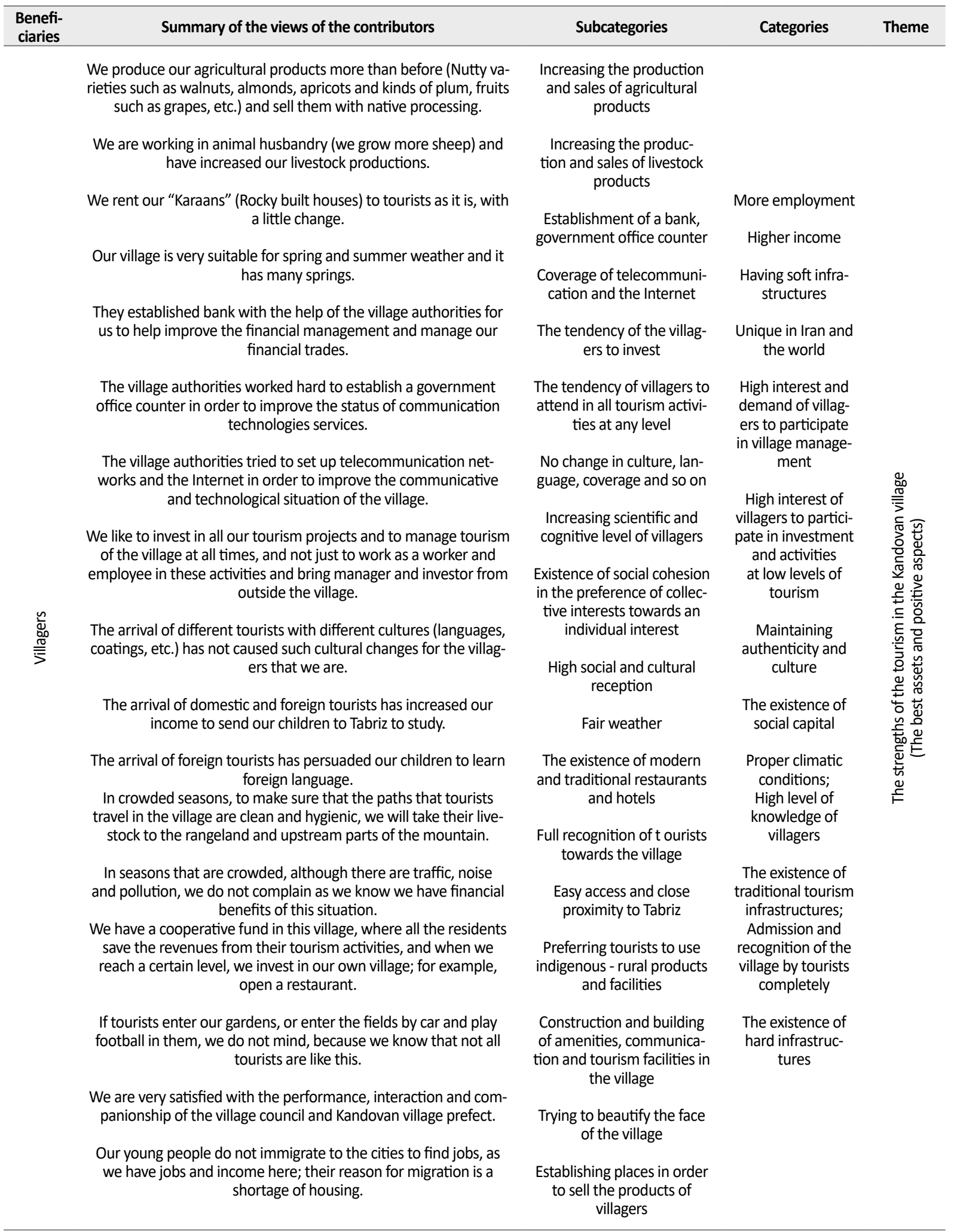




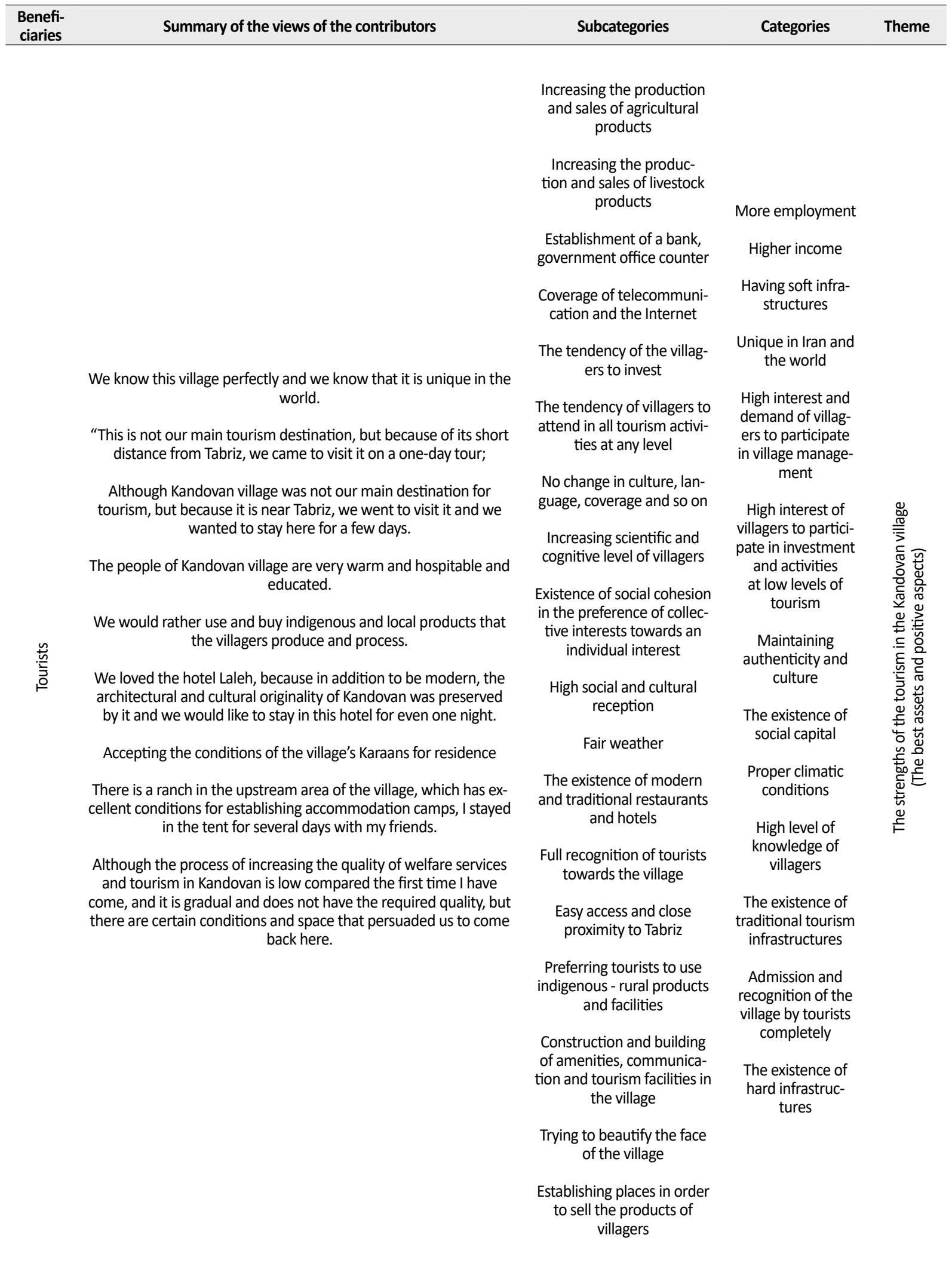




\begin{tabular}{llll}
\hline $\begin{array}{l}\text { Benefi- } \\
\text { ciaries }\end{array}$ & Summary of the views of the contributors & Subcategories & Categories \\
\hline
\end{tabular}

We built a significant number of restrooms for this village.

We developed the communication path (asphalt road) in the Kandovan village.

We built car parking for the Kandovan village.

We built many altars next to the village and along the river

Kandovan village is in the list of UNESCO World Record Candidate

and we are interacting with the villagers for formal registration

(the construction of a new Kandovan to preserve the old Kandovan).

We want to move the eclectic masts and beams from the underground to make the village have a better face.

We built a traditional marketplace near the river of the village.

Construction of alcoves for accommodation of tourists.

ment needs such as quality of life and pride of a place. With regard to rural destinations, to achieve competitive advantage, they have to utilize their asset base wisely. To this end, rural communities need to identify and draw upon all internal capacities to develop their tourism offer within the destination (Haven-Tang \& Sedgley, 2014).

The prerequisite for achieving spatially and socially balanced regional development is through tourism, namely smoothening destination-level power imbalances through integrating stakeholders in destination governance (Oliver \& Jenkins, 2003; Saxena \& Ilbery, 2008; Stoffelen \& Vanneste, 2015).

Local distinctiveness as key aspect of tourism development can help the destination enhance its territorial identity, exploit local values, attract tourists, and create a different image for a sustainable tourism strategy. Positioning and promotional strategies should rely on unique characteristics to stand out a destination. The attributes of the destination image are identified and connections are made to the concept of rurality and tourism conceptions. The image of rurality appears to be ideally positive and market-oriented. The research findings emphasize on the concept of the globalized rural idyll, which includes natural wonders, romanticism, authenticity, and nostalgia as core elements (Bell, 2006), and reintroduce the concept of the rural gaze in rural tourism research (Abram, 2003).

By focusing on society-based tourism in Kandovan heritage and mountainous village, this research was introduced by using the strategic planning process, while familiarizing with the capabilities and positive points in tourism in Kandovan mountainous village, to develop tourism in this village. To this purpose, the strengths, opportunities, and aspirations of the tourism sector of this village were determined given the nature of the SOAR strategy, after discussing with the various influential individuals and groups in the tourism of this village. The expected results in the development of tourism of rocky village of Kandovan were extracted as follows:

People have inevitably forced to build the brick houses along these Karaans, i.e., the rocky houses that have been built in the heart of rocks. With the increase of the village population and expansion of the village over time, the brick houses that have been built in today's style have become more and more, that gives an ugly face to the village. One side lies the beautiful Karaans and houses built in the heart of the rocky nature and on the other side lies the brick houses that is a clear contradiction.

Even in many cases, the villagers used non-stone materials to repair and reconstruct their rocky-stone Karaans. This matter has led UNESCO to refrain from registering the village in a permanent form, because it believes that these brick houses has destroyed the natural beauty of the village. Wires that conduct electricity to the stone houses of the village have damaged the beauty of the village, and even these electric wires are obvious in images that are taken from the village. Therefore, it is suggested that a new Kandovan be built near the village, and according to a study that was conducted, there is a land to 
Table 3. Strengths, opportunities and their related aspirations

\begin{tabular}{|c|c|}
\hline Opportunities & $\begin{array}{l}\text { S1 - Increasing employment in the tourism sector; } \\
\text { S2- Increasing income resulted from tourism ; } \\
\text { S3- The existence of soft infrastructures; } \\
\text { S4 - To be unique in Iran and the world; } \\
\text { S5 - Universal Temporary Registration on UNESCO } \\
\text { S6 - Current Life in the village } \\
\text { ment; } \\
\text { S7 - High interest and demand of villagers to participate in village manage- } \\
\text { S8 - High tendency of villagers to participate in investment; } \\
\text { S9- Maintaining the village's authenticity and culture; } \\
\text { S10-The existence of a rich and wide social capital; } \\
\text { S11- Proper climatic conditions; } \\
\text { S12 - Mineral treatment water to treat kidney stones; } \\
\text { S13 - Strange natural architecture of the village and the genus of Karaans } \\
\text { and crests from volcanic rocks with high density and hardness; } \\
\text { S14- Coolness in the houses (Karaans) and their warmth in the winter and } \\
\text { its architectural significance; } \\
\text { S15- High knowledge and scientific level of villagers; } \\
\text { S16- The existence of traditional tourism infrastructures; } \\
\text { S17 - Admission and recognition of the village by tourists completely; } \\
\text { S18- The existence of hard infrastructures. }\end{array}$ \\
\hline $\begin{array}{l}\text { O1 - Government investment through unused credits; } \\
\text { O2 - Proximity to the metropolis of Tabriz, the capital of } \\
\text { the Islamic countries 2018; } \\
\text { O3 - Plenty and various medicinal plants in the grass } \\
\text { and plains around the village; } \\
\text { 04- The presence of grasslands and fruitful products of } \\
\text { villagers with good weather around Kandovan; } \\
\text { O5 - The turning point of Kandovan tourism in Tabriz } \\
\text { 2018; } \\
\text { O6 - Free domestic and international advertisements; } \\
\text { O7- Creating Kandovan Tourism Brand to achieve } \\
\text { universal registration; } \\
\text { 08- Possibility for the presence of foreign investors; } \\
\text { O9- Development of soft infrastructures; } \\
\text { O10- Development of hard infrastructures; } \\
\text { O11-The presence of loyal tourists; } \\
\text { 012- Codification of educational-developmental } \\
\text { programs. }\end{array}$ & $\begin{array}{l}\text { Aspirations } \\
\text { S9, O5- Universal permanent registration of the Kandovan village on } \\
\text { UNESCO; } \\
\text { S4, O7 - Kandovan village as a tourist pillar of rural heritage in Iran; } \\
\text { S4, O6 - Kandovan village as the Rural Tourism Brand of the Iran in the } \\
\text { World; } \\
\text { S1, } 01 \text { - Employment in tourism field for all residents of the village; } \\
\text { S8, O1, O8- Increasing incentives of domestic and foreign investors; } \\
\text { S9, S10, S12, O11, O12 - Kandovan village as the pillar of sustainable rural } \\
\text { tourism development in Iran; } \\
\text { S12, 012 - In the village of Kandovan, every villager as a tourist guide; } \\
\text { S3, S4, S9, S15, O6, O9, O10 - Kandovan village as the destination of } \\
\text { domestic and foreign events; } \\
\text { S9, S10, S11, O11 - Kandovan village main promenade of East Azerbaijan } \\
\text { Province; } \\
\text { S14, 09, 010 - Kandovan village , a village with all the amenities and tour- } \\
\text { ism facilities of tourism; } \\
\text { S9, S10, 03, O4- Kandovan village with original and beautiful environment } \\
\text { and sightseeing. }\end{array}$ \\
\hline
\end{tabular}

build the new Kandovan near the village. Then, the residents of brick houses move there and the existing brick houses be destroyed. As a result, Kandovan regains its old and natural temperament and UNESCO standards be observed to some extent.
In addition, the underground transmission of electricity, despite its high cost, can accelerate the global registration of the village. The existence of brick houses is one of UNESCO's reasons for not registering the Kandovan globally, and although the implementation of UNESCO 
Table 4. Compilation of results through a collection of strengths and opportunities and its adaptation to aspirations and ideals

\begin{tabular}{|c|c|c|}
\hline & Strengths & Opportunities \\
\hline \multirow[t]{2}{*}{$\begin{array}{l}\text { Strategic } \\
\text { research }\end{array}$} & $\begin{array}{c}\text { - Increasing employment; } \\
\text { - Increasing in income; } \\
\text { - The existence of soft infrastructures; } \\
\text { - To be unique in Iran and the world; } \\
\text { - Temporary global registration on UNESCO } \\
\text { - The current life in it; } \\
\text { - High tendency and demand of villagers to partici- } \\
\text { pate in village management; } \\
\text { - High tendency of villagers to participate in invest- } \\
\text { ment and activities at low levels of tourism; } \\
\text { - Maintaining authenticity and culture; } \\
\text { - Rich and wide social capital; } \\
\text { - Proper climatic conditions; } \\
\text { kidney stones; } \\
\text { - Therapeutic mineral water for the removal of } \\
\text { - The strange natural architecture of the village and } \\
\text { the material of Karaans and boulders from volcanic } \\
\text { rocks with high density and hardness; } \\
\text { - Coolness inside houses (Karaans) and their } \\
\text { warmth in the winter and its architectural signifi- } \\
\quad \text { cance. } \\
\text { - High knowledge and scientific level of villagers; } \\
\text { - The existence of traditional-historical tourism } \\
\text { infrastructures; } \\
\text { - Admission and recognition of the village by tour- } \\
\text { ists completely; } \\
\text { - The existence of hard infrastructures. }\end{array}$ & $\begin{array}{l}\text { - Governmental investment through unused credits of tourism } \\
\text { sector; } \\
\text {-To be near to Tabriz Metropolitan Capital of Islamic Countries } \\
\text { in 2018; } \\
\text { - The plenty of medicinal plants in the grass and plains around } \\
\text { the village } \\
\text { - The presence of grasslands and green villages with a lot of } \\
\text { products and good weather around Kandovan; } \\
\text { - The turning point of Kandovan tourism in Tabriz in 2018; } \\
\text { - Free domestic and international advertisements; } \\
\text { - Creating Kandovan Tourism Brand to achieve global Registra- } \\
\text { tion; } \\
\text { - Possibility for the presence of foreign investors; } \\
\text { - Development of soft infrastructures; } \\
\text { - Development of hard infrastructures; } \\
\text { - The presence of loyal tourists; }\end{array}$ \\
\hline & Aspirations & Results \\
\hline $\begin{array}{l}\text { Positive } \\
\text { decisions }\end{array}$ & $\begin{array}{c}\text { - Global registration of Kandovan village on } \\
\text { UNESCO; } \\
\text { - Kandovan village as a tourist pillar of rural heri- } \\
\text { tage in Iran; } \\
\text { - Kandovan village as a rural tourism brand for Iran } \\
\text { in the world; } \\
\text { - Employment in tourism related areas for all inhab- } \\
\text { itants of Kandovan village; } \\
\text { - Increasing incentives for domestic and foreign } \\
\text { investors; } \\
\text { - Kandovan village as the pillar of sustainable devel- } \\
\text { opment of rural tourism in Iran; } \\
\text { - In the village of Kandovan, every villager as a tour- } \\
\text { ism guide; } \\
\text { - Kandovan village as the destination of domestic } \\
\text { and foreign events; } \\
\text { - Kandovan village, main promenade of East Azer- } \\
\text { baijan Province; } \\
\text { - Village of Kandovan, a village with all amenities, } \\
\text { tourism facilities; } \\
\text { - Kandovan village with original and beautiful envi- } \\
\text { ronment and sightseeing's. }\end{array}$ & 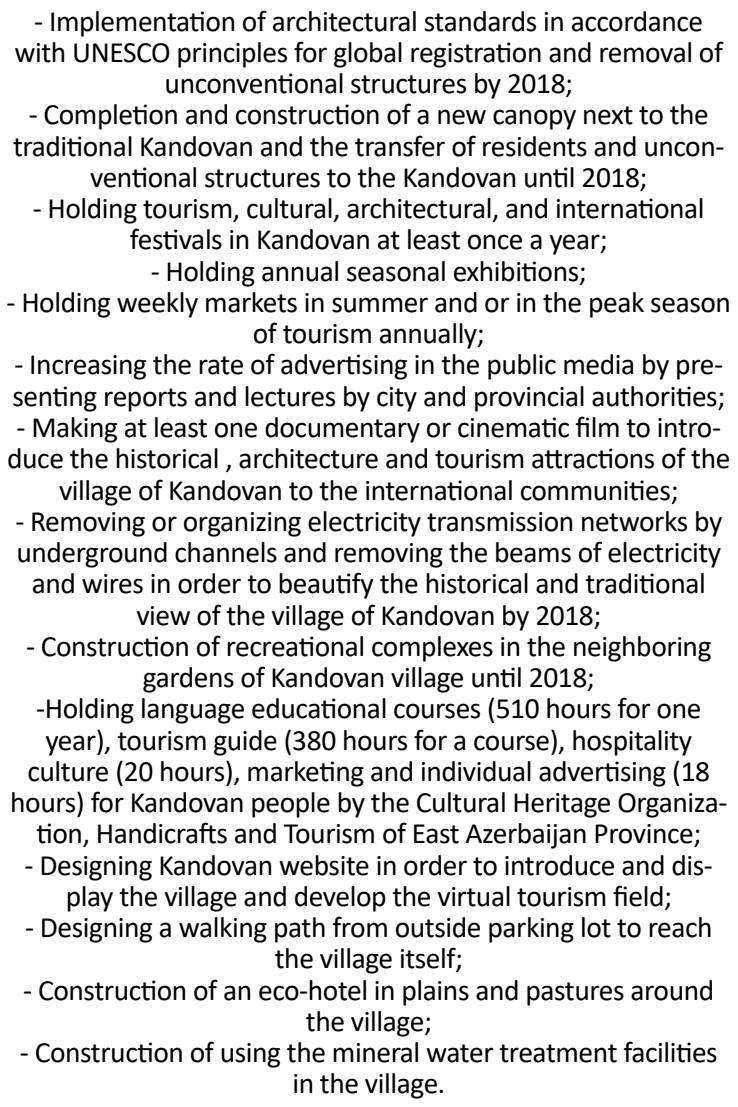 \\
\hline
\end{tabular}


standards can cost a lot, but the global registration of this village has many benefits.

Kandovan is near to the metropolis of Tabriz and selecting this city as the capital of the Islamic countries in 2018 at the Niger Summit is a valuable opportunity for Kandovan to be introduced to the Islamic world. Kandovan has been located $45 \mathrm{~km}$ from modern city of Tabriz and no doubt, advertisements are necessary for making well known the village to visitors of Tabriz 2018 and attract many visitors. This matter leads to the international popularity of Kandovan and a lot of tourists visiting the village and the same visitors will transfer their experiences of their travel and encourage other people to this village.

Holding the tourism, cultural, architecture, and sports festivals in the seasons of year that fewer tourists visit this village can boost the tourism of the village. Because holding a variety of festivals will bring a huge people to the area, also the news coverage of these events in the media, such as magazines, newspapers, television, radio and the Internet (virtual apps), helps introduce the village nationally and internationally.

In the seasons that there is a traffic of tourists, basically from mid-May to late September, holding weekly markets in the path of the village square and offering and supplying village products such as honey, walnuts, raisins, and various mountain plants can help the economic growth of the villagers and encourage them to provide better services to tourists. The majority of the villagers believe that while many tourists damage their gardens and trees and, at times of high traveling, cause traffic inside village, they welcome the arrival of the tourist to the village.

Today, film and serial production in special places greatly help in introducing and identifying the considered location. We suggest that movies and serials are produced in Kandovan village in accordance with the customs and culture of the village, which have effects on the tourist attraction and tourism development. Providing a report on civilian operation and tourism development in this area by authorities in the media, especially TV, helps the region's advertisement growth rate in image form.

The construction of a promenade and a park is recommended for the well-being of tourists in order to develop the tourism of this village, considering the presence of extensive pastures around the village. Because many local tourists travel to the village during a one-day tour, the presence of tourism resort and facilities in this village leads to the general welfare of tourists.

On the other hand, the construction of parking at the entrance of the village is one of the works that should be done with the prediction of the tourist population in the busy seasons. Parking has been constructed now in the village entrance, but it takes a long distance to reach the center of the village, so it is better to set up markets in the path of parking to village so that villagers can sell their products and also tourists pass the distance from the parking lot to the village with pleasure and enjoy and be satisfied with walking a few kilometers from the parking lot to the village center.

The village of Kandovan is adjacent to many green villages, as well as beautiful pastures and plains. Therefore, the establishment of an eco-hotel in this region in addition to developing tourism helps preserve the environment of the region. In this village, the Laleh Kandovan Hotel, has been built in the rocky cliffs like many houses of village and is the only village hotel. It is full of tourists from May to late September, and therefore the construction of special hotels in this area can be good idea.

During this research, what was clearly seen is the rich culture of the village people in dealing with the tourists and their public awareness about the unique nature of the Kandovan village, how to deal with the tourists, making the welfare for tourists, and even the standards of UNES$\mathrm{CO}$ for the global registration of Kandovan. This matter shows that the villagers have the required potential to learn a series of educational courses. The youth of the village (despite the fact that after marriage and lack of enough housing in the village, have immigrated to the surrounding cities) continue to do their business in the village and commute between the village and the city they live during the tourist season. Considering the young generation's loyalty to their hometown and their desire to work in their village, many of them are ready to participate in the development of tourism of village and, as a result, holding educational courses from the Cultural Heritage and Tourism Organization of the region such as Foreign language courses, tourism guides, hospitality culture, marketing and advertising are welcomed by young people.

This unique village in the world still has no official website. Therefore, the design of the village website and providing information about its unique features, history, paths leading to the village, the products and achievements of the villagers, the introduction of the hotel Laleh Kandovan as a luxury accommodation and at the same 
time traditional and rental rocky houses on this website will play a significant role in the development of tourism.

In the valley at the foot of the village flows the mineral water spring that has been recently plumbed. The water of this spring has been well-known for long time due to its curative nature and in the past even many people from towns and villages around have stayed there for at least one week and drank water of spring every morning and ran in the plains and mountains around the village to repel the kidney stone or bladder. Today, many tourists are aware of the therapeutic nature of the spring water and benefit from water, but the basic and engineering piping of this spring and the use of its water in healthy way and the introduction of its therapeutic properties to all tourists can affect the development of tourism in the region.

In sum, if the purpose of rural tourism development is to sustain and play a positive role in rural life, native and specific approaches should be determined and developed according to environmental management, to develop the local participation, sustainable marketing, and realistic programming.

\section{Acknowledgements}

This research did not receive any specific grant from funding agencies in the public, commercial, or not-forprofit sectors.

\section{Conflict of Interest}

The authors declared no conflict of interests.

\section{References}

Abram. S. (2003). The rural gaze. In P. J. Cloke (Ed.), Country Visions (pp. 31-48). Harlow: Pearson.

Akbari, S., Bemanian, M. R. (2008). [Rural ecotourism and its role in the sustainable development of Kandovan Village (Persian)]. Village and Development, 11(1), 131-50.

Ashley, C., Boyd, C., \& Goodwin, H. (2000). Pro-poor tourism putting poverty at the heart of the tourism agenda. ODI Natural Resource Perspectives, 51, 1-6.

Bahrami, H., Naderi Khorshidi, A., \& Kasirinejad, T. (2010). [What are the implications of strategic planning and the study of its common patterns (Persian)]. Scientific Journal of Police Development, 7(33), 11-32.

Bell, D. (2006) Variation in the rural idyll. In P. J. Cloke, T. Marsden \& P. Mooney (Eds.), Handbook of rural studies (pp. 149-60). London: Sage Publications. doi: 10.4135/9781848608016.n10
Eslami, A., \& Sabri, H. (2008). [Kandovan: Lost paradise (Persian)] Tabriz: Homazar Publishing.

Figueiredo, E., \& Raschi, A. (2013). Fertile links? Connections between tourism activities, socioeconomic contexts and local development in european rural areas. Florence: Firenze University Press.

Firouzabadi, A., \& Ghasemi, M. (2009). [The study of the role of tourism in rural sustainable development (Case study: Hasanlou, Balyghchi, Kozegaran and Shaykh Marouf) (Persian)]. Social Sciences, 17(37), 91-114.

Fleischer, A., \& Pizam, A. (1997). Rural tourism in Israel. Tourism Management, 18(6), 367-72. doi: 10.1016/s0261-5177(97)00034-4

Garfield, D. (1999). Tourism at world heritage cultural sites: The site manager's handbook. Madrid: World Tourism Organization.

Garrod, B., Wornell, R., \& Youell, R. (2006). Re-conceptualising rural resources as countryside capital: The case of rural tourism. Journal of Rural Studies, 22(1), 117-28. doi: 10.1016/j. jrurstud.2005.08.001

George, E. W., \& Reid, D. G. (2005). The power of tourism: A metamorphosis of community culture. Journal of Tourism and Cultural Change, 3(2), 88-107. doi: 10.1080/09669580508668489

Ghaderi, Z., \& Henderson, J. C. (2012). Sustainable rural tourism in Iran: A perspective from Hawraman Village. Tour ism Management Perspectives, 2(3), 47-54. doi: 10.1016/j tmp.2012.03.001

Ghasemzadeh, B. (2013). An opportunity for tourism development with troglodytic architecture. Research Journal of Applied Sciences, Engineering and Technology, 5(12), 3294-7.

Girard, T. C., \& Gartner, W. C. (1993). Second home second view. Annals of Tourism Research, 20(4), 685-700. doi: 10.1016/01607383(93)90091-g

Haven-Tang, C., \& Sedgley, D. (2014). Partnership working in enhancing the destination brand of rural areas: A case study of Made in Monmouthshire, Wales, UK. Journal of Destination Marketing \& Management, 3(1), 59-67. doi: 10.1016/j. jdmm.2013.12.001

Inskeep, E. (1991). Tourism planning: An integrated and sustainable development approach. New York: Van Nostrand Reinhold.

Karppi, I., Kokkonen, M., \& Lähteenmäki-Smith, K. (2001). SWOT-analysis as a basis for regional strategies. Stockholm: Nordregio.

Khavarian Garmsiri, A. R., Stavers, Zh. M., \& Aliyan M. (2013). [Strategic planning of urban tourism development with use SOAR strategic model (Case study: Taft City) (Persian)]. Spatial Planning (Modares Human Sciences), 17(3), 127-43.

Ko, D. W., \& Stewart, W. P. (2002). A structural equation model of residents' attitudes for tourism development. Tourism Management, 23(5), 521-530. doi: 10.1016/s0261-5177(02)00006-7

Kumar, A. (2005). SOARing to success: A process model for integrated personal, social and career development (MSc. thesis). Luton: University of Bedfordshire.

Lane, B. (2009). Rural tourism: An overview. In T. Jamal, \& M Robinson (Eds.), The SAGE Handbook of Tourism Studies (pp. 354-370). London: SAGE Publications. 
Lankford, S. V., \& Howard, D. R. (1994). Developing a tourism impact attitude scale. Annals of Tourism Research, 21(1), 121-39. doi: 10.1016/0160-7383(94)90008-6

Mair, H. (2006). Global restructuring and local responses: Investigating rural tourism policy in two Canadian communities. Current Issues in Tourism, 9(1), 1-45. doi: $10.1080 / 13683500608668237$

McIntosh, A. J., Hinch, T., \& Ingram, T. (2002) Cultural identity and tourism. International Journal of Arts Management, 4(2), 3949.

Misiura, S. (2006). Heritage marketing. Oxford: ButterworthHeinemann.

Moghimi Oskoei, H. R., \& Mosazade, E. (2007). Osku: From Oromiye Beach by Sahand Zenith; Analyze of Tourism Attractions (Persian)]. Osku: Osku Municipality Pub.

Molera, L., \& Pilar Albaladejo, I. (2007). Profiling segments of tourists in rural areas of South-Eastern Spain. Tourism Management, 28(3), 757-67. doi: 10.1016/j.tourman.2006.05.006

Moscardo, G. (2001). Cultural and heritage tourism: The great debates. In B. Faulkner, G. Moscardo, \& E. Laws (Eds.), Tourism in the Twenty-First Century: Reflections on Experience, (pp. 3-17). London: Continuum.

Oliver, T., \& Jenkins, T. (2003). Sustaining rural landscapes: The role of integrated tourism. Landscape Research, 28(3), 293-307. doi: $10.1080 / 01426390306516$

Park, D. B., \& Yoon, Y. S. (2009). Segmentation by motivation in rural tourism: A Korean case study. Tourism Management, 30(1), 99-108. doi: 10.1016/j.tourman.2008.03.011

Pearce, D. (1997). The roles of the public sector in conservation and tourism planning. In W. Nuryunti (ed.), Tourism and heritage management (pp. 88-100). Yogyakarta: Gadjah Mada University Press.

Pearce, P. L. (1995). From culture shock and culture arrogance to culture exchange: Ideas towards sustainable socio-cultural tourism. Journal of Sustainable Tourism, 3(3), 143-54. doi: 10.1080/09669589509510719

Piccard, M. (1996). Baft cultural tourism and touristic culture. Singapore: Archipe lago Press.

Reid, D. G., Mair, H., \& George, W. (2004). Community tourism planning. Annals of Tourism Research, 31(3), 623-39. doi 10.1016/j.annals.2004.01.007

Rezaei, M. R., Khavarian Garmsir, A. R. (2014). [Strategic planning of industrial area development using soar strategic framework (Case study: Yazd City industrial area) (Persian)] Journal of Arid Regions Geographics Studies, 5(18), 77-94.

Robinson, M. (1999). Is cultural tourism on the right track. UNESCO Courier, 52, 22-23.

Robinson, M., \& Smith, M. (2006). Politics, power and play: The shifting contexts of cultural tourism. In M. K. Smith. \& M. Robinson (Eds.), Cultural tourism in a changing world: Politics, participation and representation. Clevedon: Channel View Publications

Rogerson, C. M. (2004). Urban tourism and small tourism enterprise development in Johannesburg: The case of township tourism. GeoJournal, 60(3), 249-57. doi: 10.1023/b:gejo.0000034732.58327.b6

Roknodin Eftekhari, A., \& Mahdavi, D. (2006). [Tourism development strategies of Lavasan village using SWOT model (Persian)]. Human Sciences Moddares, 10(2), 1-30.

Saxena, G., \& Ilbery, B. (2008). Integrated rural tourism a border case study. Annals of Tourism Research, 35(1), 233-54. doi: 10.1016/j.annals.2007.07.010

Scott, A., Christie, M., \& Midmore, P. (2004). Impact of the 2001 foot-and-mouth disease outbreak in Britain: implications for rural studies. Journal of Rural Studies, 20(1), 1-14. doi: 10.1016/ s0743-0167(03)00032-9

Daneshpour, S. A., \& Pajouh, H. D. (2013). Cultural landscape assessment of rural districts in order to Cultural Ecosystem Services (CES) (Case Study: Sahand Rural District Landscape; Kandovan Village). Journal of Social Issues \& Humanities, 1(5), 210-217.

Sharifzadeh, A., \& Moradi Nejad, H. (2002). Sustainable Development and Rural Tourism. Monthly of Jihad, 250,251, 52-63.

Sharpley, R. (2007). Flagship attractions and sustainable rural tourism development: The case of the Alnwick Garden, England. Journal of Sustainable Tourism, 15(2), 125-43. doi: $10.2167 /$ jost604.0

Sharpley, R., \& Craven, B. (2001). The 2001 foot and mouth crisis; Rural economy and tourism policy implications: A Comment. Current Issues in Tourism, 4(6), 527-37. doi $10.1080 / 13683500108667901$

Sharpley, R., \& Vass, A. (2006). Tourism, farming and diversification: An attitudinal study. Tourism Management, 27(5), 1040-52. doi: 10.1016/j.tourman.2005.10.025

Silbert, J. H., \& Silbert, T. (2007). SOARing from SWOT: Four lessons every strategic plan must know. AI Practioner, 1-4.

Stavros, J. M., \& Hinrichs, G. (2011). The thin book of® SOAR Building strengths-based strategy. Bend: Thin Book Publishing.

Stavros, J., \& Saint, D. (2009). SOAR: Linking strategy and OD to sustainable performance. In W. Rothwell., J. Stavros, R. Sullivan, \& A. Sullivan (Eds.), Practicing organization development: A Guide for leading change (pp. 377-94). San Francisco: JosseyBass Change.

Stavros, J., \& Sprangel, J. (2008). Case study: Applying appreciative inquiry to deliver strategic change: Orbseal Technology Center. In S. Lewis, J. Passmore, \& S. Cantore (Eds.), Appreciative inquiry for change management: Using AI to facilitate organizational development (pp. 210-26). London: Kogan Page Publishers.

Stoffelen, A., \& Vanneste, D. (2015). Institutional disintegration and regional development implications of whisky tourism in speyside, scotland. Scandinavian Journal of Hospitality and Tourism, 16(1), 42-60. doi: 10.1080/15022250.2015.1062416

Timothy, D. J. (1997). Tourism and the personal heritage experience. Annals of Tourism Research, 24(3), 751-4.

Urry, J. (1990). The tourist gaze: Leisure and travel in contemporary societies. London: Sage.

Williams, F., \& MacLeod, M. (2005). The peripherality, tourism and competitiveness mix: Contradictory or confirmed. In E. 
Jones, \& C. Haven Tang (Eds.), Tourism SMEs, service quality and destination competitiveness (pp. 39-57). Wallingford: CABI.

Wilson, S., Fesenmaier, D. R., Fesenmaier, J., \& Van Es, J. C. (2001). Factors for success in rural tourism development. Journal of Travel Research, 40(2), 132-8. doi: 10.1177/004728750104000203 
